\title{
Correlation of Thyroid Hormone Derangement with Serum Ferritin Level in Children with Beta Thalassaemia Major at a Tertiary Care Hospital of Bangladesh
}

\author{
Karim $\mathrm{AKMR}^{1}$, Islam $\mathrm{MR}^{2}$, Matin $\mathrm{A}^{3}$, Deeba $\mathrm{F}^{4}$, Fakir $\mathrm{MHJ}^{5}$, Islam $\mathrm{MR}^{6}$
}

\begin{abstract}
Background: Thalassaemia is a heterogeneous group of disorders. In multi-transfused thalassaemia major patients the thyroid gland function has been reported to be normal, decreased reserve, or primary hypothyroidism. Objective: This study was an attempt to know the thyroid function status in multi-transfused thalassaemic patients and it's correlation with iron overload. Methods: This cross sectional study was carried out in the Department of Pediatrics at Bangabandhu Sheikh Mujib Medical University (BSMMU) and Transfusion centre of Bangladesh Thalassaemia Samity, Dhaka during May 2011 to April 2012. Previously diagnosed cases of thalassaemia major patients with transfusion dependent at any age with both sexes were randomly selected for this study. Serum total thyroxine (T4), total triiodothyronine (T3), thyroid stimulating hormone (TSH) and serum ferritin level were estimated from venous blood. Results: A total of 50 previously diagnosed cases of thalassaemia major patients of which 30 male and 20 female of 4 to 15 years age, transfusion dependent were randomly selected for this study. Hypothyroidism was present in $10(20 \%)$ patients. Among these 10 patients compensated primary hypothyroidism was in $5(10 \%)$ cases and decompensate primary hypothyroidism was $5(10 \%)$ cases. The TSH value of hypothyroid patients was higher. Serum ferritin value was significantly higher in all the three groups of thalassaemic patients. There was no significant correlation between the high serum ferritin value with thyroid stimulating hormone or serum total thyroxin level. Conclusion: All transfusion dependent thalassaemic patients need periodic evaluation of thyroid function because there was incidence of hypothyroidism. [J Shaheed Suhrawardy Med Coll 2013;5(2):87-90]
\end{abstract}

Keywords: $\beta$-thalassaemia, serum T4, T3, TSH, Serum ferritin level, Correlation

Received: July 2013; Revised: August 2013; Accepted: September 2013

\section{Introduction}

The thalassaemias are a heterogeneous group of disorders with a genetically determined reduction in the rate of synthesis of one or more types of normal haemoglobin polypeptide chain. In $\beta$-thalassaemia the inadequate production of $\beta$ chain leads to a reduction in the amount of $\mathrm{Hb}-\mathrm{A}$ in the red cells ${ }^{1}$.

Thalassaemia was originally described in people of Mediterranean origin. Now it is a disorder with a widespread geographical distribution ${ }^{1}$. The world population of carriers of $\beta$-thalassaemia trait is reported to be more than 100 million and about 70,000 children with thalassaemia major are born each year. In Bangladesh no definite data exists. A conservative World Health report estimates that $3 \%$ of populations are carriers of $\beta$-thalassaemia and $4 \%$ are carriers of $\mathrm{Hb}-\mathrm{E}$ in Bangladesh. This means that there are 3.6 million carriers of ?-thalassaemia and 4.8 million carriers of Hb-E. More than two thousand thalassaemic children are born every year in Bangladesh ${ }^{2}$.

Expensive iron chelation therapy is not available to majority of them, as a result of which various organ damage are responsible for significant morbidity and mortality ${ }^{3}$.

1. Dr. A.K.M. Rezaul Karim, Assistant Professor, Pediatrics OSD, Directorate General of Health Services, MOHFW, Dhaka

2. Dr. Md. Rafiqul Islam, Associate Professor, Department of Pediatrics, Shaheed Suhrawardy Medical College, Dhaka

3. Dr. Abdul Matin, Assistant Professor, Department of Pediatrics, Shaheed Suhrawardy Medical College, Dhaka

4. Dr. Farzana Deeba, Assistant Professor, Department of Obstetrics \& Gynecology. Bangabandhu Sheikh Mujib Medical University, Dhaka

5. Dr. Md. Hasan Jamal Fakir, Assistant Professor, Department of Pediatrics, Comilla Medical College, Comilla

6. Dr. Md. Reazul Islam, Medical Officer, Dhaka National Medical Institute \& Hospital, Dhaka

\section{Correspondence}

Dr. Md. Rafiqul Islam, Associate Professor, Department of Pediatrics, Shaheed Suhrawardy Medical College and Hospital, Dhaka - 1207, Bangladesh; Email: rafiq.1956@yahoo.com; Cell phone: 01715067652

Conflict of interest: None

Financial Support: None

Contributions by authors: AKMRK, MRI were involved in protocol preparation to data analygis, AM, FD, MHJF \& MRI contributed in manuscript writing \& revised the manuscript 
Transfusion related iron overload is the primary therapeutic complication in thalassaemia ${ }^{4}$. Beside heart and liver, endocrine organs of the body bear the brunt of iron mediated insult ${ }^{5}$. Many endocrine deficiencies were attributed to the deposition of iron in endocrine glands of thalassaemic patients ${ }^{6}$. Endocrine abnormalities includes panhypopituitarism ${ }^{7}$, abnormal secretion of luteinizing hormone ( $\mathrm{LH})$ and follicle stimulating hormone $(\mathrm{FSH})^{8}$, hypogonadism $^{9}$, hypoparathyroidism ${ }^{10}$, elevated serum adrenocorticotropic hormone (ACTH) level with decreased adrenal cortical reserve ${ }^{11}$ and diabetes mellitus ${ }^{12}$.

Beside various causes, iron overload is an important, although rare etiological factor in thyroid failure ${ }^{13,14}$. The thyroid gland function in thalassaemia major has been reported to be normal, decreased reserve, or primary hypothyroidism. The total serum T4 and T3 are measured by radioimmunoassay. Serum TSH levels reflect the anterior pituitary gland sensing the level of circulating free $\mathrm{T} 4$, is measured by immune-radiometric assay which is the most sensitive, convenient, and specific test for the diagnosis of both hyperthyroidism and hypothyroidism ${ }^{15}$. Serum ferritin estimation is the most widely used method for monitoring the total iron load ${ }^{16}$.

The present study was designed to estimate the serum levels of total T4, total T3, TSH and serum ferritin in multi-transfused thalassaemic patients and to see any correlation between thyroid hormone dysfunction and high serum ferritin value.

\section{Methodology}

This cross sectional study was carried out in the department of pediatrics of Bangabandhu Sheikh Mujib Medical University (BSMMU) and Transfusion centre of Bangladesh Thalassaemia samity, Dhaka during May 2011 to April 2012. A total of 50 previously diagnosed cases of thalassaemia major, 30 male and 20 female from 4 years to 15 years age, who are transfusion dependent attended the blood transfusion centre of Bangladesh thalassaemia samity were randomly selected. The parents were explained about the purpose of the study. Both the written \& verbal consents were taken from the parents without any coercion. When parents did not give consent for any particular case next case was selected. Children with family history of thyroid dysfunction, visible goiter, suggestive history of congenital hypothyroidism, any acute illness, and drugs known to alter thyroid function were excluded from the study. All information's were recorded in pre tested semi structured questionnaire. Ethical clearance was taken from institutional ethical review board. Eight $\mathrm{ml}$ of venous blood was drawn aseptically on the morning of attendance for regular blood transfusion of thalassaemic children. Time between last blood transfusion and sample collection were minimum two weeks. Serum was separated by centrifuging at $3000 \mathrm{rpm}$ for 5 minutes. The clear supernatant serum was taken in 2 screw capped dry clean vials, $1 \mathrm{ml}$ for T3, T4 and TSH estimation in one vial $1 \mathrm{ml}$ for serum ferritin estimation in another vial. Tests were carried out as early as possible after sample collection.
Whenever there was delay in estimation, samples were preserved at $-20^{\circ} \mathrm{C}$. Serum total thyroxine (T4), serum total triiodothyronine (T3) and thyroid stimulating hormone (TSH) level were estimated by Radioimmunoassay (RIA) and Immunoradiometric assay (IRMA) technique respectively in the laboratory of Institute of Nuclear Medicine of BSMMU. Serum ferritin level was estimated by chemiluminescent method in the laboratory of microbiology department of BSMMU. For Statistical analysis, ANOVA test was used and $\mathrm{P}<0.05$ was considered as level of significance.

\section{Results}

A total of 50 thalassaemic patients were included in this study. The age of patients ranged from 4-15 years with a mean of $7.65 \pm 3.61( \pm 1 \mathrm{SD})$, consists of 30 males and 20 females (Table-I).

\section{Table 1: Demographic Profile of Study Population}

\begin{tabular}{lc}
\hline Variables & Value (Mean \pm SD) \\
\hline Age & $7.65 \pm 3.61($ Range $4.0-15.0)$ \\
Sex & $30(60.0 \%)$ \\
- Male & $20(40.0 \%)$ \\
\hline
\end{tabular}

Thyroid dysfunction (hypothyroidism) was present in $10(20 \%)$ patients out of fifty thalassaemic patients. Among these 10 patients $5(10 \%)$ had compensated primary hypothyroidism known as Group-II in which elevated TSH but normal T4 and T3 was detected; on the other hand 5(10\%) had decompensate primary hypothyroidism which was known as Group-Ill in which patients had elevated TSH but low T4 and normal T3. Forty $(80 \%)$ patients were euthyroid designated as Group I (Figure I).

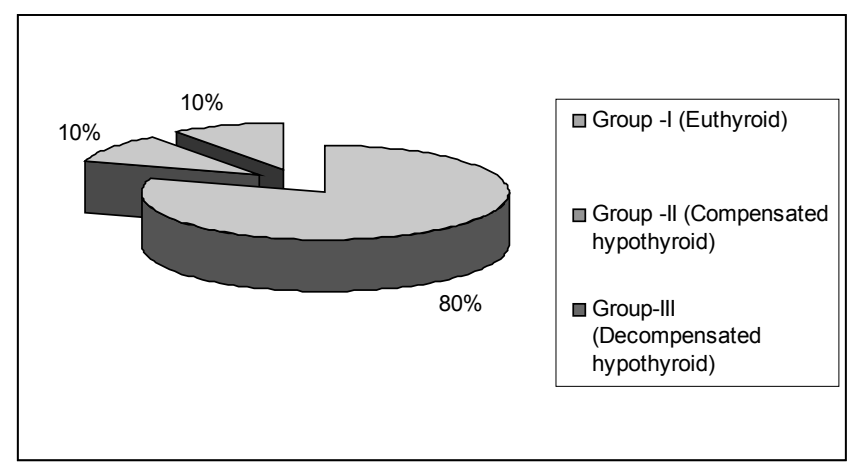

Figure 1: Different Groups of Thalassaemic Patients According to Thyroid Function Status

One patient belonged to decompensate group had clinical symptoms and signs suggestive of hypothyroidism. The patient was 15 years old male who complained of marked increase in weight despite average appetite, lethargy, cold intolerance and mental dullness. None had goiter. The TSH value of hypothyroid patients (Group-II and group-Ill) was higher. The mean T4 of decompensate hypothyroid (GroupIll) patients were lower (Table 2). 
Table 2: Comparison of Thyroid Function Tests In Between Three Different Groups of Cases

\begin{tabular}{ccccc}
\hline Group & Parameters & $\mathbf{T}_{\mathbf{3}}(\mathbf{n m o l} / \mathbf{L})$ & $\mathbf{T}_{\mathbf{4}}(\mathbf{n m o l} / \mathbf{L})$ & TSH $(\boldsymbol{\mu I U} / \mathbf{L})$ \\
\hline Group I & Mean \pm SD & $1.87 \pm 0.61$ & $133.92 \pm 39.76$ & $3.15 \pm 1.85$ \\
40 cases $(80 \%)$ & Range & $0.86-3.09$ & $65.18-197.33$ & $0.80-5.96$ \\
Group II & Mean \pm SD & $1.98 \pm 1.01$ & $130.06 \pm 28.37$ & $8.61 \pm 1.24$ \\
5 cases (10\%) & Range & $0.84-3.16$ & $93.23-171.62$ & $7.13-9.70$ \\
Group III & Mean \pm SD & $1.75 \pm 1.07$ & $45.04 \pm 12.92$ & $8.61 \pm 1.24$ \\
5 cases (10\%) & Range & $0.87-3.48$ & $40.07-56.55$ & $7.13-9.70$ \\
Normal value & Range & $0.8-3.54$ & $54-175$ & $0.3-6$ \\
\hline
\end{tabular}

The mean T3 of thalassaemic patients were lower but was within the normal range (Normal range of T3 0.8-3.54 nmol/L, T4 54-175 nmol/L, TSH 0.3-6 ? IU/L /L) (Table 3).

Table 3: Serum T3, T4, TSH and ferritin level in study children

\begin{tabular}{lccccc}
\hline \multicolumn{2}{l}{ Parameters } & $\begin{array}{c}\mathrm{T}_{3} \\
(\mathrm{n} \mathrm{mol} / \mathrm{L})\end{array}$ & $\begin{array}{c}\mathrm{T}_{4} \\
(\mathrm{n} \mathrm{mol} / \mathrm{L})\end{array}$ & $\begin{array}{c}\mathrm{TSH} \\
(\mathrm{IU} / \mathrm{L})\end{array}$ & $\begin{array}{c}\text { Ferritin } \\
(\mathrm{ng} / \mathrm{ml})\end{array}$ \\
\hline Study & Mean $\pm \mathrm{SD}$ & $1.87 \pm 0.70$ & $124.63 \pm 42.66$ & $5.30 \pm 8.09$ & $2407.33 \pm 1866.33$ \\
value & Range & $0.84-3.48$ & $24.50-197.33$ & $0.80-58.47$ & $497.50-12730.00$ \\
Ref. value & Range & $0.8-3.54$ & $54-175$ & $0.3-6$ & $7.0-140.0$ \\
\hline
\end{tabular}

Serum ferritin value was significantly higher in all the three groups of thalassaemic patients yet no significant difference could be found between the various groups (Table 4). There was no significant correlation between the high serum ferritin value with thyroid stimulating hormone or serum total thyroxin level (Figure 16 \& 17).

Table 4: Comparison of Serum Ferritin Value between Three Groups of Thalassaemic Patients

\begin{tabular}{lccc}
\hline \multirow{2}{*}{ Group } & \multicolumn{2}{c}{ Serum ferritin } & \multirow{2}{*}{ P value ${ }^{\mathrm{a}}$} \\
\cline { 2 - 4 } & Range & Mean \pm SD & \\
\hline Group I & $497.50-12730.00$ & $2458.79 \pm 2023.40$ & I vs II : NS \\
Group II & $1200.00-3910$ & $2252.00 \pm 1147.79$ & II vs III : NS \\
Group III & $1070.00-3670.00$ & $2151.00 \pm 1200.23$ & I vs III : NS \\
\hline
\end{tabular}

*Group I: Euthyroid patients; Group II: Compensated hypothyroid patients, Increased TSH, normal T3 and T4; Group III: Decompensate hypothyroid patients, Increased TSH, Normal T 3 and low T4; a=ANOVA test; Ns- Not significant

\section{Discussion}

Present study was undertaken to estimate the serum levels of total T4, T3, TSH and serum ferritin in multi-transfused $\beta$-thalassaemia major patients and correlation of thyroid hormone dysfunction with high serum ferritin value. Here primary hypothyroidism was seen in $20 \%$ cases out of 50 apparently euthyroid thalassaemic patients. Only 2\% patient of them had frank symptoms of hypothyroidism. Subclinical deficiency of thyroid hormone (compensated or decompensate hypothyroidism) was present in another $18 \%$ patients. The mean $\mathrm{T} 3$ of the thalassaemic patients and mean T4 of decompensate hypothyroid patients were lower. Mean TSH of the hypothyroid cases and serum ferritin value of thalassaemic patients were higher. This observation of thyroid hypofuntion in the present study was not similar to the findings of Costin et $\mathrm{al}^{6}$, Kuo et $\mathrm{al}^{9}$, who found normal thyroid function in thalassaemic patients.
However, Flynn et $\mathrm{al}^{10}$ found mean $( \pm 1 \mathrm{SD})$ serum thyroxin was lower in thalassaemic children. The mean value for serum thyroid stimulating hormone was raised in thalassaemic patients. Sabato et $\mathrm{a}^{13}$ demonstrated primary subclinical hypothyroidism in $17.50 \%$ of the 114 thalassaemic patients. Agarwal et $\mathrm{al}^{17}$ reported hypothyroidism in $19.4 \%$ thalassaemic patients out of 72 cases. Of whom $12.5 \%$ suffered from compensated hypothyroidism and $6.9 \%$ suffered form decompensated hypothyroidism. Two (2.78\%) patients belonging to decompensated hypothyroidism group suffered from symptomatic hypothyroidism. Jain and his coworkers 18 observed subclinical hypothyroidism in $32 \%$ of his study population of thalassaemia major, but none of them had clinical symptoms and signs suggestive of hypothyroidism. Present study findings were similar to the observation of Flyan et $\mathrm{al}^{10}$, Sabto et $\mathrm{al}^{13}$, Cavallo et $\mathrm{al}^{14}$, Agawal et $\mathrm{al}^{17}$, Jain et $\mathrm{al}^{18}$ and Phenekos et al ${ }^{19}$.

In thalassaemia major, iron deposition in endocrine gland as a consequence of chronic iron overloading by regular transfusion therapy had been documented histologically ${ }^{6}$. All the patients of this study had mild iron overload according to WHO criteria ${ }^{20}$, except one patient. Probably for this reason iron overload had no major contribution in thyroid hypo function in the present study. This observation did not support the findings of Al-Hader et $\mathrm{al}^{4}$ who found that thyroid hypofunction is common in thalassaemic patients with iron overload. Agarwal et $\mathrm{al}^{17}$ and Masala and his coworker ${ }^{21}$ did not observe any significant correlation between iron overload and thyroid status.

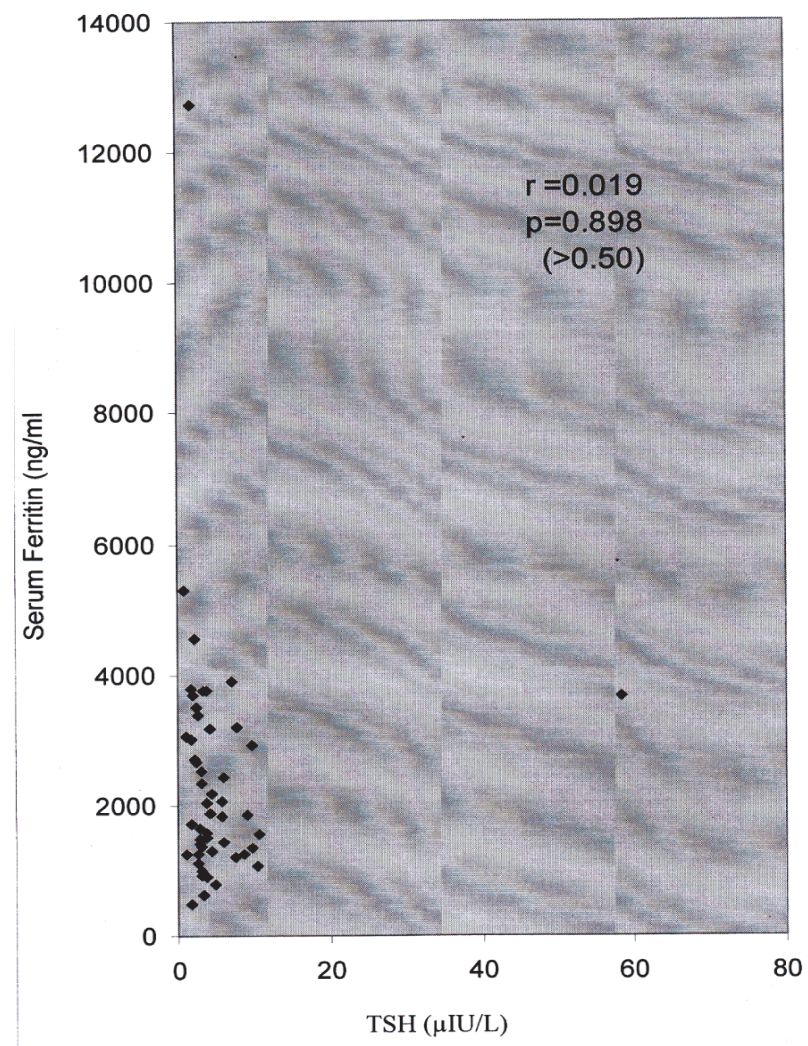

Fig. 16 Correlations between the serum ferritin and TSH level 


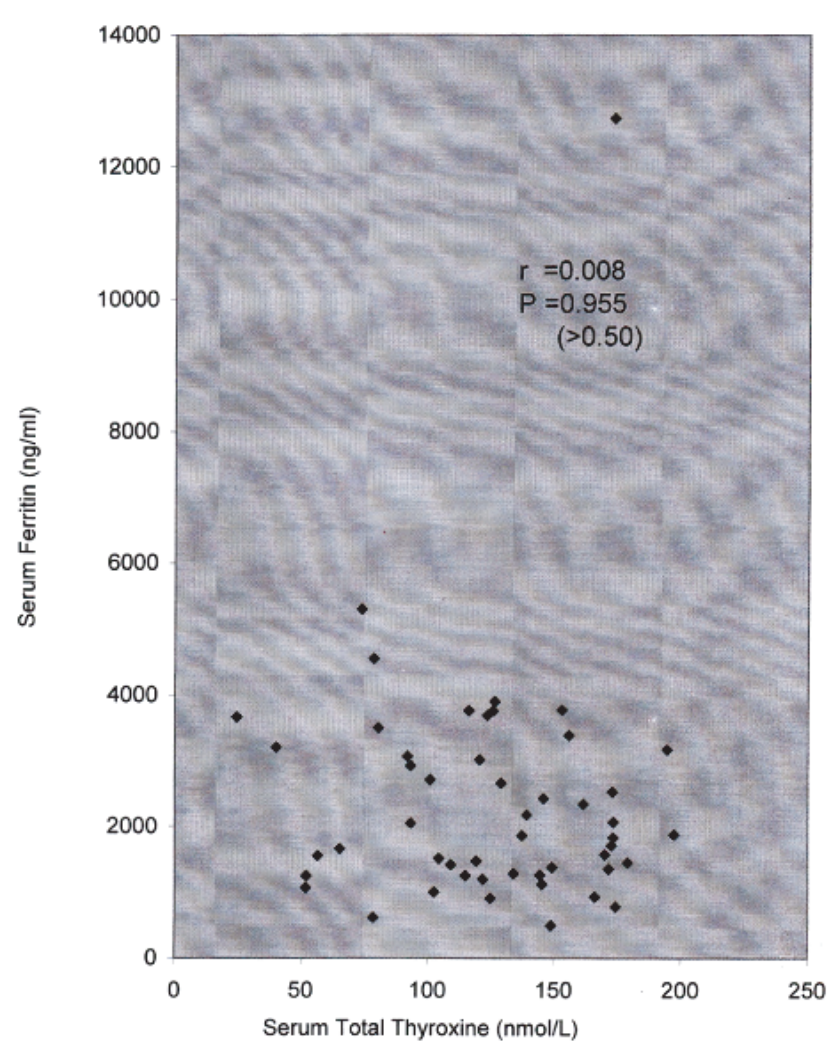

Fig. 17 Correlation between serum ferritin and serum total thyroxine $\left(\mathrm{T}_{4}\right)$

Besides iron overload there seem to be other factors which contribute to endocrine damages in thalassaemic patients. Hypoxia due to chronic anaemia can cause tissue damage and may contribute to endocrine dysfunction ${ }^{17}$. It was postulated that in patient with thalassaemia, the damage resulting from anemia and hypoxia could be greater than from transfusion induced haemosiderosis ${ }^{6}$.

Liver dysfunction could play some role in hormone derangement as metabolism of various hormones was altered when the liver is damaged ${ }^{22}$. Liver may be affected in $\beta$-thalassaemia due to haemosiderin induced hepatocyte necrosis and fibrosis, transfusion associated hepatitis, which ultimately leads to hepatic cirrhosis ${ }^{22}$. This study showed few cases of hypothyroidism in multi-transfused thalassaemic patients but no significant correlation between the high serum ferritin value with thyroid stimulating hormone or serum total thyroxin level.

\section{Conclusion}

It may be concluded that all transfusion dependent thalassaemic patients need periodic evaluation of thyroid function because the incidence of hypothyroidism is substantial and they may benefit from thyroid hormone replacement therapy.

\section{References}

1. Olivieri NF. The ?-Thalassemias. N Engl J Med 1999; 341:99-109

2. WHO Working Group. Hereditary anaemias: genetic basis, clinical features, Diagnosis, and treatment. Bulletin of the World Health Organization 1982; 60(5):643-660

3. Agarwal MB. Living with Thalassaemia. 1st Edi. Bombay, Bhalani Book depot, 1986

4. Al-Hader AF, Bashir N, Hasan Z, Khatib S. Thyroid function in children with ?-thalassaemia major in North Jordan. Trop Paediat 1993;39: 107- 110

5. Modell B, Berdoukas V.Growth, puberty and endocrinopathy. In: Modell B, Berdoukas V(eds). The clinical Approch to Thalassaemia, 1st edition, New York: Grune and Stratton, 1984;175-197.

6. Costin G, Kogut MD, Hyman CB, Ortega JA. Endocrine Abnormalities in Thalassaemia Major. Am J Dis Child 1979; 133:497-502

7. Bannerman RM, Keusch G, Kreimer-Birnbaum M, Vance VK. Thalassaemia Intermedia, with Iron Overload, Cardiac Failure, Diabetes Mellitus, Hypopituitarism and Porphyrinuria. Am J Med 1967; 42:476-486 8. Kletzky OA, Costin G, Marrs RP, Bernstein G, March CM, Mishell DR Jr. Gonadotropin insufficiency in patients with thalassaemia major. J Clin Endocrinol Metab 1979;48 : 901-905

9. Kuo B, Zaino E, Roginsky MS. Endocrine function in thalassaemia major. J Clin Endocrinol 1968;28:805-8

10. Flynn DM, Fairney A, Jackson D, Clayton BE. Hormonal changes in thalassaemia major. Arch of Dis Child 1976; 51:828 -836

11. Mclntosh N. Endocrinopathy in thalassaemia major. Arch Dis Child 1976; 51:195-201

12. Costin G, Kogut MD, Hyman C,Ortega J. Carbohydrate metabolism and pancreatic islet-cell function in thalassaemia major. Diabetes 1977; 26: 230-240

13. Sabato AR, De Sanctis V, Atti G, Capra L, Bajni B, Vullo C. Primary hypothyroidism and the low T3 Syndrome in thalassaemia major. Arch Dis child 1983;58:120-7

14. Cavallo L, Mautone A, Altomare M. Pituitary-thyroid function in children with $\beta$-thalassaemia major. Acta Endocr Copenh 1981;96:59-64

15. Beckett G, Rae P. Thyroid function tests. Med International 1993; 6:155-160

16. Walters GO, Miller FM, Worwood M. Serum ferritin concentration and iron stores in normal subjects. J Clin Path 1973;26:770-772

17. Agarwal MB, Shah S, Vishwanathan C, Rajadhyaksha G, Bhave AA, Dube SR, et al. Thyroid dysfunction in multi-transfused iron loaded thalassemia patients. Indian Pediatr 1992;29:997-997

18. Jain M, Sinha RSK, Chellani H, Anand NK. Assessment of thyroid functions and its role in body growth in thalassemia major. Indian Pediatrics 1995;32:213-213

19. Phenekos C, Karamerou A, Pipis P, Constantoulakis M, Lasaridis J, Detsi $\mathrm{S}$, et al. Thyroid Function In Patients With Homozygous $\beta$ Thalassaemia. Clin Endocrinol 1984;20(4):445-450

20. WHO. Update of the progress of haemoglobinopathies control. Reports of a WHO working group WHO/WG/85.5

21. Masala A, Meloni T, Gallisai D, Alagna S, Rovasio PP, Rassu S, et al. Endocrine functioning in multitransfused prepubertal patients with homozygous $\hat{I}^{2}$-thalassemia. J Clin Endocrinol Metab 1984;58(4):667-670 22. Jean G, Terzoli S, Mauri R, Borghetti L, Di Palma A, Piga A, et al. Cirrhosis associated with multiple transfusions in thalassaemia. Arch Dis Child 1984;59(1):67-70 